\title{
Download
}

UDC 311. 3:318 https://doi.org/10.17721/2308-135X.2021.64.13-20

Beznosiuk Olena Taras Shevchenko National University of Kyiv, Kyiv, Ukraine,

e-mail: beznosiukoi.kvb@gmail.com, https://orcid.org/0000-0003-0563-4507

\section{INTANGIBLE CULTURAL HERITAGE AS A MODERN TOURIST RESOURCE ON THE EXAMPLE OF SPAIN}

The aim. To explore the prospects of creative and imaginative tourism based on intangible cultural heritage on the example of Spain.

Methodology. General scientific research methods are used, namely general scientific: comparison, analysis, synthesis, generalization and analogy. The comparison method was used to establish the similarity of the use of $\mathrm{ICH}$ elements as a tourist magnet. Methods of analysis, synthesis and generalization were used in the study of the causal relationship between the growth of tourist activity in Spain due to the introduction of legislative documents that contributed to this process and the preservation of cultural traditions of local communities. By analogy, we can expect a probable positive result of the development of creative and imaginative tourism in Ukraine.

Results. Positive and effective examples of relevant types of cultural tourism in Spain are considered. The article illustrates the examples of places in Spain where creative models of tourism development have been adopted in recent decades. Successful results of relevant types of cultural tourism in the country are considered in the research. It has been exemplified how important tourist "magnets" from the UNESCO Representative List became the elements of intangible culture of Spain.The article illustrates the examples of places in Spain where creative 
models of tourism development have been adopted in recent decades. Successful results of relevant types of cultural tourism in the country are considered in the research. It has been examplified how important tourist "magnets" from the UNESCO Representative List became the elements of intangible culture of Spain.

Scientific novelty. The author explores how creative tourism, changing the traditional model of cultural tourism heritage, departs from material culture. The considered experience demonstrates that creativity is a mobile component. Creativity promotes interaction between the owners of intangible culture, which are mostly locals from rural areas, and visitors. The role of owners is not the traditional one for tourism as services are not provided in a traditional way, but in the form of demonstration, training or transfer of experience. The role of tourists in this case is the search for new skills, knowledge or experience.

Practical meaningfulness. The study provides examples of how the key acquisition becomes a new symbolic capital, i. e. the acquisition of experience, worldview and skills. Practical cases of cooperation and distribution of roles between local communities and the state in tourism development based on the use of $\mathrm{ICH}$ elements between have been described.

Key words: creative tourism, sustainable tourism, sustainable development, elements of intangible cultural heritage, tourist "magnets", "smart tourism network".

\section{References}

1. Beznosyuk O.I., Vakulenko N.V. (2020). Intangible cultural heritage as a tool for creating a tourist product and a source of socio-economic development of local communities /Tourism and hospitality. Pinsk,1, 28-37. (in Belarus)

2. Wine Horses. Retrieved from: https://ich.unesco.org/en/RL/wine-horses-00860\#video (Accessed 15 May 2021).

3. Dem'yan V. V. Intangible cultural heritage as a field of interdisciplinary interaction. The culturology ideas. 2018. 14, 161-169. (in Ukrainian). DOI: 
https://doi.org/10.37627/2311-9489-14-2018-2.161-169 (Accessed 7April 2021).

4. Intelligent location. Implementation of digital conversion. Retrieved from:

http://www.esri.ua/templater.php?link=location-intelligence (Accessed 15 May 2021).

5. Castells are human towers. Retrieved from:

https://ich.unesco.org/en/RL/human-towers-00364 (Accessed 26 June 2021).

6. International Forum on Creative Tourism. Retrieved from:

http://www.creativetourismnetwork.org/conferences/ (Accessed 30 June 2021).

7. Summer solstice fire festivals in the Pyrenees. Retrieved from:

https://ich.unesco.org/en/RL/summer-solstice-fire-festivals-in-the-pyrenees-01073 (Accessed 26 June 2021).

8. Patum of Berga. Retrieved from:

https://ich.unesco.org/en/RL/patum-of-berga-00156\#diaporama (Accessed 15 May 2021).

9. Presentation, Missions \& Services. The Creative Tourism Network $\circledast$ is the international organization for the creative tourism development worldwide. Retrieved from:

http://www.creativetourismnetwork.org/presentation/ (Accessed 30 June 2021).

10. Cultural tourism research program ATLAS. Retrieved from:

https://www.richardstourism.com/atlas-cultural-tourism-project (Accessed 04 June 2021).

11. Tamboradas drum-playing rituals. Retrieved from:

https://ich.unesco.org/en/RL/tamboradas-drum-playing-rituals-01208\#video (Accessed 15 May 2021). 
12. Valencia Fallas festivity. Retrieved from:

https://ich.unesco.org/en/RL/valencia-fallas-festivity-00859\#video (Accessed15 May 2021).

13. Mystery play of Elche. Retrieved from:

https://ich.unesco.org/en/RL/mystery-play-of-elche-00018 (Accessed 17 May 2021).

14. Text of the Convention for the Safeguarding of the Intangible Cultural Heritage Retrieved from: https://ich.unesco.org/en/convention (Accessed 07 April 2021).

15. Festivity of 'la Mare de Déu de la Salut' of Algemesí. Retrieved from:

https://ich.unesco.org/en/RL/festivity-of-la-mare-de-deu-de-la-salut-of-algemesi-00576\#video (Accessed 17 May 2021).

16. Government portal. Official website. Retrieved from

https://www.kmu.gov.ua/news/oleksij-chernishov-prioriteti-velikogo-budivnictva-2021-proekti-roz vitku-socobyekti-ta-turistichni-magniti (Accessed 30 April 2021).

17. Flamenco. Retrieved from: https://ich.unesco.org/en/RL/flamenco-00363\#video (Accessed 30 April 2021).

18. Fiesta of the patios in Cordova. Retrieved from:

https://ich.unesco.org/en/RL/fiesta-of-the-patios-in-cordova-00846\#video (Accessed 16 May 2021).

19. ATLAS Cultural Tourism Bibliography. 2021.65 c. URL:

https://www.academia.edu/48864997/ATLAS_Cultural_Tourism_Bibliography (Accessed 03 June 2021).

20. Ilincic, Milica. 2013. «Benefits of Creative Tourism The Tourist Perspective». Paper presented at Expert Meeting on Alternative and Creative tourism in cities on in Barcelona. 
Meeting was organised by ATLAS City and National Capital Tourism Special Interest Group, ATLAS Cultural Tourism Special Interest Group and Creative Tourism Network. June 13-14. P. 99-113. URL:

https://www.academia.edu/10102778/Benefits_of_Creative_Tourism_The_Tourist_Perspective (Accessed 26 June 2021).

21. Richards, G. Cultural tourism: A review of recent research and trends. Journal of Hospitality and Tourism Management. 2018. № 36. P. 12-21, doi:

https://doi.org/10.7202/1041585ar.URL:https://www.researchgate.net/publication/326247209_C ultural_Tourism_A_review_of_recent_research_and_trends (Accessed 03 June 2021).

22. Official site of UNESCO. Browse the Lists of Intangible Cultural Heritage and the Register of good safeguarding practices. URL: https://ich.unesco.org/en/lists?exemplary=1 (Accessed 15 May 21).

23. Official Tourism Portal of Spain. URL: https://www.spain.info/en/ (Accessed 15 May 2021). 